\title{
Industrial Discipline and Disciplinary Proceedings Mechanism in Industry in Bangladesh
}

Nusrat Hasina' ${ }^{1}$ A. S. M. Zahidul Islam ${ }^{2}$

${ }^{1}$ Senior Lecturer, Department of Law, Leading University, Sylhet, BANGLADESH

${ }^{2}$ Manager, Human Resources, Ananta Group, Mirpur; Dhaka-1216, BANGLADESH

*Corresponding Contact:

Email: shampanusrat@yahoo.com

Cell Phone: +8801717134094

\begin{abstract}
Industrial Law, though it has grown prolific in recent years, lacks in one vital aspect, that is, it has no clear and understandable disciplinary procedure. Disciplinary action can be taken by the employer against an employee committing any misconduct mentioned in the statutory law and punishment can be awarded as deemed suitable in the circumstances of the case after making an enquiry as may be necessary. But principles of disciplinary action is not laid down anywhere in any enactment or any other rules framed so far. The result is that each employer has his own idea of discipline and his own method of its enforcement. Since so uniform guidelines of discipline exist in industrial law, an employer even though he wishes to be fair to the delinquent employee, often commits procedural errors which is natural in the absence of such guiding rules. This paper aims to improve our understanding the gap between existing law and real scenario relating to industrial discipline and disciplinary proceedings mechanism in industry in Bangladesh. This lacuna has, however, been made good by judicial pronouncement dealing with every aspect of disciplinary events in the industry. A domestic enquiry is based mainly on the principles of natural justice and procedure laid down by various decisions of the Apex Court which now provide for guiding principles in disciplinary action in industrial concerns.
\end{abstract}

Keywords: misconduct, conduct disciplinary authority, preliminary enquiry, charge-sheet Suspension, defenses, discipline, disciplinary action, punishment

\section{JEL Classification Code: K3}

\section{INTRODUCTION}

Employees or human resources are perhaps the most valuable asset of any organization. It is the human resource that exploits other resources in the organization so as to achieve the organizational objectives. The aim of the human resource department by whatever name it is known such as Personnel Department, Employee Relations Department, etc. is to get the best productivity of the human resource of the organization. For achievement of this purpose, there 
are many sub-systems in the human resource department such as grievance handling, counseling, performance appraisal, career planning, training \& development, etc. Reward and punishment system is one of the sub-systems under the human resource system. Today, employees are protected by different statutory laws. Employees have the right to protest, make claims, file litigation, and seek damages, if they believe they have been mistreated at any stage of the employment relationship. At present, no employer can succeed in punishing an employee, unless he has committed an act of misconduct as enumerated in the Bangladesh Labor Act, 2006 and the Bangladesh Export Processing Zones Authority Instructions No 1, 1989 which has been proved in an enquiry. The Bangladesh Export Processing Zones Authority Instructions No 1, 1989 is applicable only inside the EPZ area, but workers working other than EPZ areas are governed by the Bangladesh Labor Act, 2006.

In the case of Karnaphuli Paper Mills Ltd. Vs. Workers Union (1961 PLC 991), Supreme Court of Pakistan held that - "But in the case of private employment, the ordinary rule of master and servant must be sustained ..........." The relation between master and servant in matters of disciplinary action is governed by principles of natural justice.

\section{Discipline \& Disciplinary Action}

The term "discipline" has no statuary definition and as such it has a wide variety of meanings in different contexts. The simple definition of discipline may be that it is a process of training a worker so that he can develop self-control and can become more effective in his work. Following principles may serve as guidelines for both the employers and employees in industry:

On the sides of the Management-

(a) There should be no undue changes in the procedure or methods of work with which the workers are accustomed, unless the exigency of work so warrants; (b) The disciplinary plan should be well-laid out and the rules be framed and widely publicized. It should be ensured that the rules have been understood by the worker; (c) Applications of the rules must be fair and just and there should be no discrimination in their application; $(d)$ There should always be a human approach to the problem and vindictive attitude should be avoided; (e) Punishment to be meted out to a worker for breach of discipline or any misconduct must commensurate with the gravity of the offence; and ( $f$ ) Rules of natural justice must be observed in an enquiry instituted against a workman.

\section{On the sides of the Workmen-}

(a) The workmen should abide by the rules of the Company, standing orders and other lawful orders of the management issued from time to time; (b) They should discharge their duties honestly and faithfully; (c) They should avoid absenteeism except on exceptional grounds; (d) They should not act or conduct themselves in such a way as cause to prejudice to the interests and reputation of the employer; (e) They should not participate in illegal strikes or activities which are subversive of discipline, such as 'go-slow' 'gherao', etc.; and ( $f$ ) They should first try to settle any dispute or difference with the employer by peaceful means.

\section{MISCONDUCT}

The word "misconduct has not defined in the industrial law, or any other enactment. It may mean various acts of omissions and commissions involving improper conduct in the discharge of duties. The word 'misconduct' though not capable of precise definition. The term misconduct implies a wrongful intention. Misconduct literally means wrong or improper conducts i.e. conduct in violation of a definite rule of action. It ordinarily means failure to do what is required of a person to be done. An omission to do what is required of a person to do may, therefore, constitute misconduct even though the person has not acted willfully or maliciously. 


\section{Misconduct under Industrial Laws of Bangladesh}

\section{The Bangladesh Labour Act, 2006}

Section-23 (4) of the Bangladesh Labour Act, 2006 listed the following acts as misconduct -

- Willful insubordination or disobedience, whether alone or in combination with others' to any lawful or reasonable order of a superior,

- Theft, misappropriation, fraud or dishonesty in connection with the employer's business or property,

- Taking or giving bribes or any illegal gratification in connection with his or any other worker's employment under the employer,

- Habitual absence without leave or absence without leave for more than ten days.

Exception: Section-27(3A) of the Bangladesh Labour Act, 2006 states that if any worker remains absent from the workplace without notice or without approval for period of more than 10 days, the employer shall serve a notice to such worker by giving specific time to explain such absence and to rejoin at work. If such worker does not explain in writing or does not join within stipulated time then another 7 days shall be given to defend him. If such worker does not join or defend him within aforesaid time, he shall be deemed to be removed from service from day of such absence.

- Habitual late attendance,

- Habitual breach of any law or rule or regulation applicable to an establishment,

- Riotous, disorderly behavior, arson or ransack in the establishment,

- Habitual negligence or neglect of work,

- Habitual disobedience or violation to any of the rules relating to conditions of service, of discipline framed by the Chief Inspector,

- Falsifying, tampering with, damaging or causing loss of employer's official records.

\section{The Bangladesh Export Processing Zones Authority Instructions No 1, 1989}

According to Section - 15(1) of the Bangladesh Export Processing Zones Authority Instructions No 1, 1989 'Misconduct' means conduct prejudicial to good order or service discipline un-becoming of an employee or a gentleman and shall include:

- Willful insubordination or disobedience, whether alone or in combination with others, to any lawful or reasonable order of a superior;

- Theft, fraud or dishonesty in connection with the business or property of the factory/ enterprise;

- $\quad$ Causing damage to any property of the factory/ enterprise;

- Taking or giving bribes or any illegal gratification;

- Habitual late attendance or habitual absence from duty without leave or without sufficient cause.

- Continuous absence for more than ten days without permission and without satisfactory cause of absence;

- Habitual breach of any law, order, instruction applicable to him;

- Habitual neglect or negligence of work;

- Willful abstension or absence from work singly or with others;

- Drunkenness, fighting \& riotous, disorderly or indecent behavior;

- Taking part in or suspected or being engaged in subversive activities either alone or with others;

- Collecting or canvassing or the collection of any money within the premises of the enterprise/ Company/ factory for any purposes not approved by the employer.

- Smoking within the premises of the company or enterprise/ factory where it is prohibited;

- Distribution or exhibition within the boundaries of the premises of the Company/ factory of any hand bill, pamphlets or poster without the previous permission of the competent authority.

- Holding meeting within the boundaries of the premises of the Company/ factory without sanction of the employer; 
- Gambling within the boundaries of the premises of the Company/ factory;

- Habitual indiscipline;

- Leaving work without permission;

- $\quad$ Sleeping while on duty;

- Theft of any kind inside the premises of the factory/ company or within the zone.

- Giving false information regarding name, age, qualifications, previous service etc.; Carrying on money lending or any other private business, within the premises of the factory/ company;

- Sabotage or wastage caused to materials \& stores of the company/ factory;

- Malingering and slowing down work either alone or in collaboration with others;

- Conviction in any court of law for any criminal offence;

- Improper use or non-use of protective clothing, uniforms (if any) while on duty

\section{DISCIPLINARY AUTHORITY}

The power to take disciplinary action has to be specially delegated to a competent authority. In this regard appointing authority is the competent authority. In the organization, there may be certain authorities who are empowered to take disciplinary action up to a particular level of employees. In many organizations, the Board of Directors delegates the power to award punishment only to the Managing Director of the company, who in turn, can re-delegate the same to other executives.

\section{STEPS OF DISCIPLINARY ACTION}

\section{The Bangladesh Labour Act, 2006}

Section-24(1) of the Bangladesh Labour Act, 2006 stated the procedures of disciplinary action against the industrial workers. According to the said Act, no order for punishment under Section 23 against a worker shall be made unless-

- The allegations against him are recorded in writing,

- He is given a copy thereof and not less than seven days' time to explain,

- He is given personal hearing if such a prayer is made,

- After enquiry, he is proved guilty, and

- $\quad$ The employer or the manager approves of such order.

\section{The Bangladesh Export Processing Zones Authority Instructions No 1, 1989}

On the other hand Section-17 of the Bangladesh Export Processing Zones Authority Instructions No 1, 1989 deals with the disciplinary action procedure against the EPZ workers. When an employee is to be proceeded against for any offence of misconduct the employer shall follow the following course of actions:

- The employer shall frame a charge sheet specifying the charges brought against an employee and communicate it to the employee concerned.

- The accused shall submit a written statement of his defense within three days from the day the charge has been communicated to him.

- The employer shall appoint an Enquiry Officer/ Committee to hold an enquiry.

- The employer may nominate any person/ officer to present the case in support of the charge sheet before the Enquiry Officer/ Committee.

- The Enquiry Officer/ Committee shall issue a notice asking the accused to appear before the Enquiry officer/ Committee at a particular place stating the specific time of appearance with a copy to the nominee of the employer/ company who will present the case in support of the charge sheet before the Enquiry Officer/ Committee.

- The Enquiry Officer/ Committee shall ask the accused to appear before the Enquiry Officer/ Committee with all documentary evidence and witnesses 
- The accused shall be entitled to cross examine the witnesses against him and he should be allowed to present witnesses in his defense.

- The Enquiry Officer/ Committee shall record the statement of the accused and witnesses of both sides.

- The Enquiry Officer/ Committee shall obtain signature of all the witnesses in their respective statements duly read over to them in the language they understand.

- If the accused admits the charge against him the Enquiry Officer/ Committee will record 'Pleads Guilty' and thereafter shall give his/ its findings.

- If the accused pleads 'not guilty' then all witnesses in support of the charge sheet will be examined individually in presence of the accused.

- No witness shall be allowed to be present during the examination of another witness.

- After being duly informed if the accused absents himself from the enquiry without proper reason or permission, the enquiry shall proceed expert.

- The enquiry shall be confined to the charges and no irrelevant evidence shall be admitted by the Enquiry Officer/ Committee.

- The Enquiry Officer/ Committee shall submit his/ its report to the employer with his/ its findings.

- The employer, having regard to the findings on the charges, shall pass appropriate orders.

\section{PreliminaRY ENQUIRY}

A preliminary enquiry is really for the satisfaction of the employer to decide whether punitive action should be taken before he decides to hold a regular enquiry and also for the purpose of collection of facts in regards. A Preliminary enquiry is normally restored to by the disciplinary authority to collect evidence and material for forming an opinion whether full-fledged disciplinary enquiry may be initiated against the delinquent employee or not.

\section{ChARge-SheET}

\section{Meaning of Charge-Sheet}

The word "Charge-Sheet" is borrowed from criminal law. But it is not used in the sense in which it has been used in Section 410 of the Criminal Procedure Code. Under the industrial law the term charge-sheet has not been defined anywhere. The ordinary meaning of "charge-sheet" is a memorandum of charges, i.e. acts of omissions alleged to have been committed by an employee. The charge-sheet consists of facts and allegations which the persons issuing a charge-sheet wants to establish against the employee committing a breach of rules or misconduct in terms of the standing orders or any act inconsistent with the fulfillment of the obligations implied in the contract of employment.

\section{Drafting of Charge-sheet}

Under Industrial Law, there is no form prescribed for a charge-sheet, there is also no hard and fast rule about it. Though different situations will require different charge-sheet, one requisite feature of every charge-sheet is that charges must be specific in all possible details. The following guidelines may be helpful for drawing up a correct charge-sheet:

- A charge must be specific, precise and intelligible and must set out all the necessary particulars. Vagueness in the wordings of a charge must be avoided.

- Charge-Sheet must not be drafted in a questionnaire format.

- The charge sheet should be in a language which is understood by the employee concerned.

- Mere mention of a particular clause of the statutory law is not enough to sustain a charge. The charge must be sufficiently described and supported by facts.

- No hint of punishment is to be given at this stage. 
- If two misconducts are constituted by the same set of facts, these are to be mentioned separately.

- The date, time and place of the occurrence are to be invariable mentioned, and the names of the persons if any, in whose presence the incident has occurred.

- Care should be taken to avoid - (a) Repetition, verbosity and ambiguity in expression; (b) Unnecessary and extraneous matter; and (c) Misdescription of the misconduct.

- It should be signed by the appointing authority, which is also the dismissing authority.

\section{Service of Charge-sheet}

The following procedure is usually to be followed regarding the issue and service of charge-sheet:

- By handing over the charge-sheet to the worker and obtaining his signature or thumb impression (if the worker is illiterate) on the office copy of the charge-sheet;

- When the worker refuses to accept the charge-sheet when called for to receive it, one copy charge-sheet must be sent by the registered post and the another copy must be exhibited on the notice board;

- In case the worker is on leave or absent without leave, the charge-sheet must be sent by the registered post.

\section{SUSPENSION}

Meaning of Suspension. The suspension is defined as a state of being debarred. An employee when he is suspended is thus debarred from any privilege, from the execution of an office or from the enjoyment of an income. It is a temporary deprivation of office but by reason of suspension the person suspended does not lose his office nor does he suffer any degradation. He only ceases to exercise the powers and to discharge the duties for the time being. It only means a temporary deprivation of office.

Kinds of Suspension., there can be three kinds of suspension:

- Interim suspension pending or in contemplation of disciplinary proceedings or domestic enquiry;

- Interim suspension pending trial for a criminal offence for the same issue;

- Suspension by the way of punishment.

When the order of Suspension can be issued? The order of suspension may be issued: (i) Just after the incident (before the charge sheet); or, (ii) Along with the charge-sheet; or, (iii) After receipt of explanation from the charge-sheeted worker.

Duration of Suspension: According to Section 24(3) of the Bangladesh Labor Act, 2006 the suspension is for sixty (60) days only and within this period enquiry has to be finished. If, for any reason, the enquiry could not be completed within this period, the worker concerned should be asked to resume work and the enquiry will continue.

Subsistence allowance during Suspension. A worker is not entitled to wages for the period of suspension pending disciplinary proceedings. During the suspension period, the worker shall get a subsistence allowance equivalent to half of his basic wages, and dearness allowance and ad-hoc of interim pay, if any and full amount of other allowance(s). On enquiry if a worker is found guilty of any of the charges alleged and is punished under Section 23(1), he shall not be entitled to his wages for any period of suspension for enquiry but shall be entitled to the subsistence allowance. If the worker is found not guilty, he shall be deemed to have been on duty for the period of suspension for enquiry, if any, and shall be entitled to his wages for such period of suspension and the subsistence allowance shall be adjusted accordingly.

Section 16(2) of the Bangladesh Export Processing Zone Instructions 1, 1989 states that if the employee concerned remains under suspension during the period of the enquiry, he will be 
entitled to subsistence allowance for the period of suspension equivalent to half of his average basic pay and full amount of house rent allowance and medical allowance.

\section{Reply to the Charge-Sheet And ITS Consideration}

Defences that can be taken up in reply to the charge-sheet. The defence of a worker to a charge of misconduct generally falls into three principal classes.

- The first is that the worker has not committed the misconduct.

- The second is that he has committed the misconduct; and

- The third is that even if the worker has committed the act alleged against him the same was justified under the circumstances and did not constitute misconduct.

Denial of guilt. When the worker does not admit the charges framed against him and tenders an explanation and does not admit the guilt or straightway denies the guilt, then in order to take further action against the worker the employer may proceed on holding a domestic enquiry against the charge-sheeted worker.

Confession. If on receipt of the charge-sheet the delinquent worker sends in his explanation in reply to the charges in which he admits the charges, then also the employer will proceed to hold the enquiry and complete the rest of the procedure to impose final punishment. Because according to Section 24(1) of the Bangladesh Labour Act, 2006 it is mandatory for the employer to hold the disciplinary proceedings though it would be merely a formality given the admission.

Admission along with an explanation. Sometimes a person makes a statement, a part of which can be construed as a confession of guilt but in another part that confession is qualified or is explained.

Reasonable time to give reply. According to Section-24(1)(b) of the Bangladesh Labor Act, 20016 no order for punishment under Section 23 against a worker shall be made unless he is given ..not less than seven days' time to explain.

\section{Enquiry CommitTee, Enquiry OfFicer \& Enquiry Notice}

\section{Selection and appointment of enquiry officer}

It is not necessary that the Enquiry Officer should be a legal expert, but he must possess a fair knowledge of the principles of natural justice since the rules of natural justice would govern the whole proceeding where there is no prescribed procedure to conduct the enquiry. During selection of Enquiry Officer(s) following points should be kept in mind:

- Enquiry Officer should have an open mind and should not have bias or prejudice against the employee concerned.

- A person having personal knowledge of the incident cannot be appointed as an Enquiry Officer.

- An Enquiry Officer cannot act as a prosecutor or witness.

- Officer of the Company can act as Enquiry Officer.

- The enquiry should be held by an officer superior in rank.

- Company's lawyer or legal adviser can act as Enquiry Officer.

- An outsider can very well act as the Enquiry Officer and he also act impartially.

- A person having personal ill-will against the delinquent worker cannot be acted as Enquiry Officer.

- Attitude of the Enquiry Officer should be like that he will treat both parties equally and courteously and come to a decision in an objective manner supported by evidence on record.

- When the enquiry is held by the enquiry committee consisting of more than one enquiry officer, the bias of one vitiates the whole enquiry. 


\section{Formation of Enquiry Committee}

The enquiry committee will be formed by the equal number(s) of representatives from employer and worker.

\section{Role \& Function of Enquiry Officer}

- The enquiry officer should prepare a recording sheet of the proceeding. The date, time and place of the enquiry should also be noted.

- To get confirmation from the employee of the receipt of charge-sheet and notice of the enquiry.

- The enquiry officer should explain to the worker the charges levelled against him in the language the accused understands.

- The enquiry officer should record whether the accused has got to say in an elaboration of, or in addition to, the explanation made him.

- The enquiry officer should ask the accused whether he pleads guilty to any, or all of the charges made in the charge-sheet.

- The enquiry officer should then ask the asked the accused if he has any documentary evidence to meet the charges or if he will produce witnesses in his defence.

- After these preliminaries are over, the enquiry officer should ask the representative of the management to present the case on behalf of the company.

\section{DOMEstic ENQUIRY - PRINCIPLES AND PROCEDURE}

The purpose of domestic enquiry is two-fold, i.e. firstly, to give the delinquent worker an opportunity to make a statement against all the charges which are made against him as well as to examine any witnesses in his defence, and to cross-examine the prosecution witnesses and secondly, to give the employer an opportunity to assess the merits of the case from the findings of the enquiry officer as well as the evidence and records produced in the case and to reach his own conclusion as to the guilt of the accused and thereafter to decide the quantum of punishment to be imposed on him or declare him not-guilty if the charges were not satisfactorily proved. General Principles to be followed in an Enquiry:

- There is no fixed rule for conducting a domestic enquiry.

- The management may assign another officer of the company to present the case on behalf before the enquiry officer.

- There is no bar to the complainant to be appointed as presenting officer by the management.

- At the time of the enquiry session the charge-sheeted worker may bring his Representative, who must be an employee of the establishment.

- An employee has no right to represented by a lawyer or a legal expert.

- The necessity of an interpreter is arisen when the charge-sheeted employee does not understand the language in which the enquiry is conducted.

- There is no need for an independent observer to sit in an enquiry and to watch it..

- The general principle is that no court should act on the statement made by a witness behind the back of the person who is charged with a particular misconduct.

- There is no rule of evidence that evidence of a solitary witness cannot be relied upon and no conclusion can be based upon the evidence of such a solitary witness.

\section{ENQUIRY REPORT}

It is the clear mandate that domestic enquiry officer, like all other quasi-judicial authorities must give reasons for his decisions. Not only reasons have to be given but also given must be proper and adequate. The report of the Enquiry Officer must be a speaking one in the sense that the conclusion is to be supported by reason. 


\section{Consideration of the Enquiry Report by the Punishing Authority}

On receiving the report of the enquiry officer it is for the punishing authority to consider whether to agree with the conclusions of the enquiry officer or not. The requirement to give consideration does not mean that the disciplinary authority must mention each of the contentions raised by the petitioner and give detailed reasons for its conclusion.

\section{AWARDING OF PUNISHMENT}

\section{Punishment}

Punishment, according to the dictionary, involves the infliction of pain or forfeiture; it is the infliction of a penalty, chastisement or castigation by the judicial arm of the State. Punishment in industrial law has no special technical significance. The word punishes as interpreted by the Court is to inflict the penalty for an offence. It means that an offence must be committed by a person before he is punished. The object of punishment is, therefore, to cause a person to suffer for his misconduct.

\section{Types of punishment}

The Bangladesh Labour Act, 2006. Major punishment: According to Section 23(1) of the Bangladesh Labour Act, 2006 although anything regarding lay-off, retrenchment, discharge and termination of service as provided elsewhere in the Act, a worker may be dismissed without prior notice or pay in lieu thereof if he is (a) Convicted for an offence, or (b) Is found guilty of misconduct.

Minor punishment: According to Section 23(2) of the Bangladesh Labour Act, 2006 - A worker guilty of misconduct may instead of dismissal be, considering special situations, given following penalties:

- Removal,

- Bringing to lower grade of the job, not more than year down to salary scale,

- Stopping promotion for not more than one year,

- Stopping increment for not more than one year,

- Fine,

- Suspension not more than seven days without pay,

- Censure or warning.

The Bangladesh Export Processing Zone Instructions 1, 1989. According to Section-16(1) of the Bangladesh Export Processing Zones Instruction 1, 1989 the following are the penalties which may be imposed by the employer upon an employee working in EPZ area:

- Censure;

- Stoppage of increment or promotion on grounds of inefficiency, irregular attendance and misbehavior;

- Recovery from the pay of the employee of the whole or part of a pay to defray any pecuniary loss caused to the company/ enterprise by negligence, default or breach of orders or of contract on the part of the employee;

- Reduction in rank;

- Dismissal from service;

\section{Communication of the order of punishment: Effective date}

The law on this point is that the order of punishment must be communicated to the delinquent employee concern. Until the order is communicated and the person concerned knows about it, the order does not become operative. 


\section{Flow Chart of Disciplinary Proceedings}

\section{STAGE 1:}

STAGE 2:

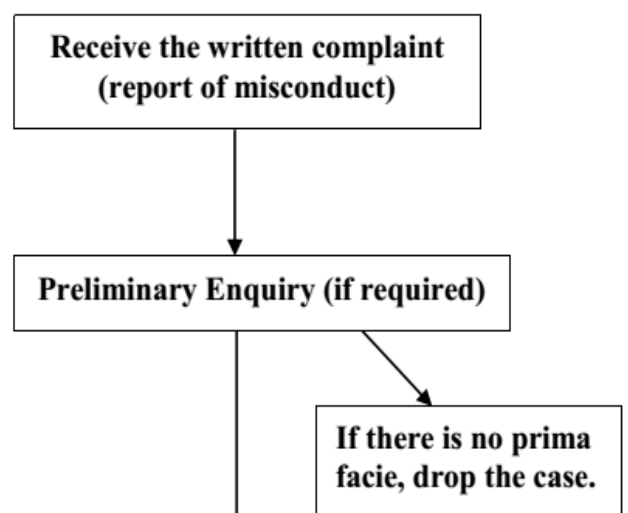

STAGE 3:

Suspension pending Enquiry (if necessary)

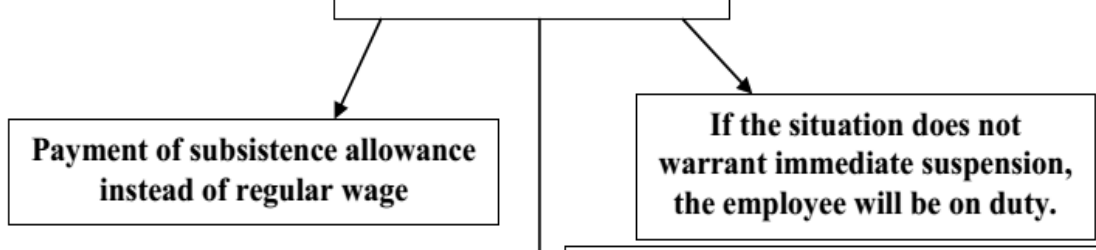

1. Suspension before the charge sheet; or,

2. Suspension along with the charge-sheet; or,

3. Suspension after receipt of explanation

STAGE 4:

STAGE 5:

\section{Framing of Charge-Sheet}

\section{Service of Charge-Sheet}

1. By handing over to the worker; or

2. Registered Post and exhibited on the notice board; 
STAGE 6:

Reply given by the charge sheeted employee

STAGE 7:

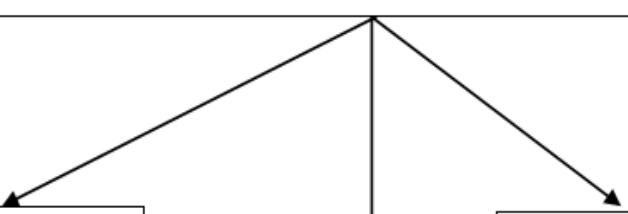

Denial of guilt

Confession

STAGE 8:

Formation of Enquiry Committee and Appointment of Enquiry Officer

STAGE 9:

Service of Enquiry Notice

1. By handing over to the worker; or

2. Registered Post and exhibited on the notice board;

STAGE 10:

1. Examination of witness

2. Record of enquiry proceedings

3. Accused and witness will sign the enquiry proceedings

Enquiry Proceedings
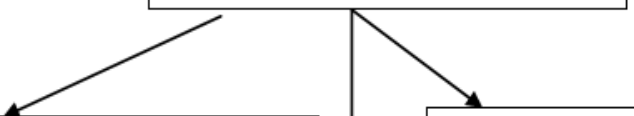

If the employee does not report for enquiry, ex-parte enquiry

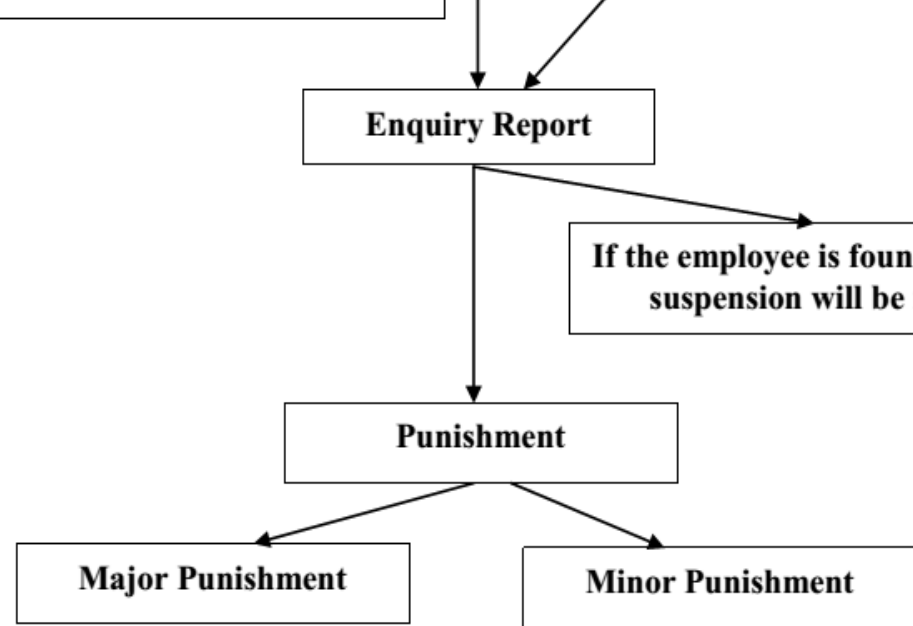




\section{DisciplinARY ACTION AGAINST THE TRADE UNION LEADERS}

Section-228(2) of the Bangladesh Labor Act, 2006 states that an officer of a trade union shall not, while any conciliation proceeding or proceedings before an arbitrator, a labor court or the tribunal in respect of an industrial dispute are pending, be discharged, dismissed or otherwise punished for misconduct, except with the previous permission of the labor court.

\section{Disciplinary Action PENDING IndUSTRIAL Dispute}

Section 228(1) of the Bangladesh Labor Act, 2006 describes the provision relating to the disciplinary action pending industrial dispute. Section 228(1) states that "no employer shall, while any conciliation proceeding or proceedings before an arbitrator, a labor court or the tribunal in respect of an industrial dispute are pending, alter to the disadvantage of any worker concerned in such dispute, the conditions of service applicable to him before the commencement of the conciliation proceedings, or of the proceedings before the arbitrator, the labor court or the tribunal, as the case may be, not shall he save with the permission of the conciliator, while any conciliation proceedings ore pending; or save with the permission of the arbitrator, the Labor court or the tribunal, while any proceedings before the arbitrator, Labor court or the tribunal, while any proceeding before the arbitrator labor court or tribunal are pending discharge, dismiss or otherwise punish any worker or terminate his service except for misconduct not concerned with such dispute."

\section{Disciplinary Proceedings Pending Criminal Cases}

When an employee committed any act that is of a criminal nature he can be prosecuted for such an offence by the Criminal Court, it does not take away the jurisdiction of superior officers to hold the domestic enquiry or to punish such delinquent employee with recourse to the Criminal Court. There is no legal prohibition that prevents the holding of enquiry of a workman just because a Criminal Case is pending against the workman. The domestic enquiry in which the workman is answerable to his mater and which may end in a departmental penalty is entirely different from the criminal proceedings in which the same person in respect of the same act is prosecuted for violation of the penal law of the land that may end in conviction or sentence.

\section{DisciplinARY ACTION DURING MATERNITY LEAVE:}

Section-50 of the Bangladesh Labor Act, 2006 states as follows "if any notice or order of discharge, dismissal, removal or otherwise termination of employment is given by the employer to a woman worker within a period of 6 (six) months before and 8 (eight) weeks after her delivery and such notice or order is given without sufficient cause, she shall not be deprived of any maternity benefit to which she would be entitled under this Act if such notice or order has not been given."

\section{Disciplinary Proceedings against the Management StafF}

According to Section-2(65) of the Bangladesh Labor Act, 2006 "a person who is employed mainly in a managerial, administrative or supervisory capacity" and according to Section2(h) of the Bangladesh Export Processing Zones Authority Instructions No 1, 1989 "any person who is employed mainly in a managerial, executive, or administrative capacity" is commonly known as Management Staff in any industrial \& commercial establishment, factory, shops \& establishment. Besides these, any manager or person responsible for the management and control of the establishment is also called Management Staff. 
According to Section-16 of the General Clauses Act, 1897 the authority having power to make the appointment shall also have the power to suspend or dismiss any person appointed whether by itself of any other authority in exercise of that power. In the case Kustia Sugar Mills Ltd. Vs. Abdul Wadud (27 DLR (HCD) 76) the court held that in the case of employees who are not governed by the statutory law, the minimum requirement is that the principles of natural justice should be followed.

\section{CONCLUSION}

In a democratic country like ours, in the matter of industrial relations, we cannot always take the position of victor and vanquished, and wait for next opportunity to retaliate. Such a negative attitude has ruined many an otherwise prosperous industrial unit, ultimately leading to its closure. There is statutory restriction relating to strikes and lockouts, but still these take place and count for million \& million man-days lost on an average every year. This scenario is not likely to change unless both the management and the workers' unions change their attitude towards the other and sit down together to draw up a strategy based on trust and mutuality for their survival. The success of any industrial organization largely depends upon the degree of discipline, efficiency and commitment of its employees. This conformity to rules and procedure should come from within. This is possible only if the management can create an atmosphere of trust and goodwill by its uniform, impartially and with compassion, wherever required. Care, concern and a compassionate approach in dealing with employees almost always strengthen the managements' capability. Management should develop their policy and practice based on the above mentioned basic principles that are developed during the last 200 years by judicial decisions of the different Apex Courts of Indian Sub-Continent.

\section{REFERENCES}

Abbasi, H. (2012). Anthropology an Intellectual Tradition and Contemporary Relevance. ABC Journal Of Advanced Research, 1(1), 47-59.

Abedin MM, Ahmed AA and Neogy TK. 2012. Mechanism of Accountability and Auditing: Public Sector Scenarios of Bangladesh Journal of Business Studies, 4, 131-148.

Ahmed AA and Neogy TK. 2010. Forensic Accounting in Bangladesh: Emergence and Introduction, Development Compilation, 3, 71-82.

Ahmed AA. 2015. Relationship between Foreign Direct Investment and Company Taxation: Case of Bangladesh American Journal of Trade and Policy, 2, 125-129.

Ahmed, Dr. Zulfiquar, A Text Book of the Bangladesh Labour Act, 2006 (Including Industrial \& EPZ Laws); $2^{\text {nd }}$ Edition, March, 2009;

Bangladesh Export Processing Zones Authority Instructions No 1, 1989;

Choudhury,Tapash Gan, Penumbra of Natural Justice; $2^{\text {nd }}$ Edition;

Chowdhury, A.B., Legal Aspect of Managing Employee Relations, Eastern Law House, 2005 edition.

Ghaiye, B. R., The Law Procedure of Departmental Enquiries; Vol - I; $2^{\text {nd }}$ Edition.

Ghaiye, B. R., The Law Procedure of Departmental Enquiries; Vol - II; $2^{\text {nd }}$ Edition.

Gupta, G P Das, Industrial Discipline - Concepts, the Law and Cases, Tata McGraw-Hill Publishing Company Limited, 1990;

Halim, Md. Abdul, Text Book on Labour \& Industrial Law of Bangladesh, 2006;

Hao, N., \& Jungkyu, P. (2013). CRN Application to Predict the NOx Emissions for Industrial Combustion Chamber.Asian Journal Of Applied Science And Engineering, 2(2), 109-126.

Haq, Syed Azadul, Bangladesh Labour Act (Unofficial English Version with Case Laws and Commentaries), 2008;

M.S. Nill's Law of Suspension; $3^{\text {rd }}$ Edition;

Mallik, M. R., K. P. Chakravarti's Domestic Enquiry \& Punishment, $3^{\text {rd }}$ Edition, Eastern Law House, Calcutta, 1998; 
Mamoria, C. B., Personnel Management, Fifth Edition, Himalaya Publishing House, 1987;

Manual-Special Training on Disciplinary Proceedings; Airports Authority of India, Corporate Vigilance Department, 2004;

P Ramanatha Aiyer's The Law Lexicon, The Encyclopedic Law Dictionary with Legal Maxims, Latin Terms and Words \& Phrases, $2^{\text {nd }}$ Edition (Extensively Revised and Enlarged), Reprint 2002, Wadhwa and Company Nagpur

Pillai, R.K., Law Relating to Domestic Enquiry; 2008 Current Publication.

Puri, Dr. S. K., An Introduction to Labour and Industrial Laws, Allahabad Law Agency, Eighth Edition, 1996;

Rahman, M. (2012). Henry Fayol and Frederick Winslow Taylor's Contribution to Management Thought: An Overview. ABC Journal Of Advanced Research, 1(2), 32-41.

Srivastava, Kirpa Dayal and Srivastava, Naresh Kumar, Disciplinary Action against Government Servants and Its Remedies; $4^{\text {th }}$ Edition -1977.

The Bangladesh Labour Act, 2006, Gazette (with upto date amendment);

Zaman, Haider, The Law of Dismissal \& Termination of Services, $2^{\text {nd }}$ Edition, Mansoor Book House, Katchery Road, Lahore, 1978.

--0-- 